\title{
Covid Economic Policy and Media Response: an Analysis of Culture and Media Content
}

\author{
Amirudin Amirudin ${ }^{*}$, Agus Subiyanto ${ }^{2}$ \\ ${ }^{1}$ Department of Anthropology, Faculty of Humanities, University of Diponegoro, Kampus Undip \\ Tembalang, Semarang - 50275, \\ Jawa Tengah, Indonesia \\ ${ }^{2}$ Department of Linguistics , Faculty of Humanities, University of Diponegoro, Kampus Undip \\ Tembalang, Semarang - 50275, Jawa Tengah, Indonesia
}

\begin{abstract}
This study explores the media's response to Indonesia's economic strategy in overcoming the impact of Covid-19 based on the assumption with the worst scenario, Indonesia will deal with an economic slowdown of minus $0.4 \%$. Most research shows the public response to the implementation of economic strategies gives a positive perception, but not necessarily with the media response. This research was conducted from 1 April to 30 April 2020, designed using content and culture analysis methods to reveal how the media responds to national economic policies with data sources from the news media. The unit of analysis in this research is news and opinions from media people (newspeople). Analysis was carried out with a taxonomic model to the national media Kompas, Detik, and Tempo to find patterns of media response. The study found that media response patterns manifested in 3 patterns: (a) supportive, (b) neutral, and (c) resistant. In general, the supporting pattern is the most prominent in the three media. This pattern is dominant because the media considers the best attitude in a crisis situation is the concern of the state. The media sees this form of concern as reflected in the economic strategy adopted to deal with the impact of Covid-19. To maintain positive media perceptions, researchers recommend that the government needs to continue to protect and mitigate vulnerable groups that are experiencing economic damage by implementing two strategies: (a) basic needs access or meeting basic needs, and (b) sustainability livelihood access or providing opportunities for vulnerable groups to have sustainable livelihoods.
\end{abstract}

Keyword: Covid-19, Media Response, Content and Cultural Analysis, National Economic Policy

\footnotetext{
* Corresponding author: amdjtg@yahoo.com
} 


\section{Introduction}

The Covid-19 pandemic continued to escalate. The global economy in 2020 is projected to continue to grow negatively or experience a recession. The global financial market panicked, causing a capital outflow which caused serious pressure on currencies, capital markets and securities globally, including Indonesia. Covid-19 escalation in Indonesia is exponential per component type of business sectors. Indonesia has made security measures, but it has not been sufficient. These steps are in the form of quick steps to prevent the spread of Covid 19 by physical distancing, work and study from home, restrictions / prohibitions on public activities, testing, tracing, and hand washing. However, challenges were still found in the form of weak community life support systems (health, food, social security). But on the other hand, thus comes a joint awareness of the government, the private sector, and the nation's potential such as Personal Protectif Equipment (PPE) production, ventilators, and masks $[1,2,3,4]$.

Indonesia's economic growth at the end of 2020 is estimated to fall $2.3 \%$, poverty rate 9.4\%, Open Unemployment Rate (OUR) 6.3\%, Gini Ratio 0.379. Under such conditions, risks to achieving the sustainable development agenda are likely to be challenged. Even escalation based on assestment with the worst scenario is likely that Indonesia could encounter an economic slowdown of minus $0.4 \%$.

Indonesia, besides trying to face the spread of Covid-19 in the country, also cannot be separated from the dynamics of the global economy. As is known, all countries are currently also focused on dealing with Covid-19, which ultimately disrupts investor confidence, the tourism sector, supply chain and financial markets. While the outlook for the global economy on the other hand continues to be compounded by the weakening of crude oil prices. To that end, the government has taken economic policy steps to overcome the multi-directional impact of the macro economy and the basic needs of vulnerable groups.

Based on economic policies as outlined in the Regulation of Lieu of Law (PERPU) No. 1 of 2020 concerning State Financial Policy and Financial System Stability for Handling Corona Virus Disease 2019 (COVID-19) and / or in the Context of Facing Threats that Harm National Economy and / or Financial System Stability. This PERPU was enacted on March 31, 2020.

Many studies $[5,6,7,8,9$,] show public perceptions of the application of economic atrocities through the PERPU gave a positive response, but not necessarily with media response. This study aims to examine the media's response to national economic policy in overcoming the impact of Covid-19 based on the assumption that with the worst case scenario, Indonesia will face an economic slowdown of minus $0.4 \%$.

\section{Method}

This study uses content analysis and culture methods to uncover media responses to the implementation of national economic policies as framed in PERPU No. 1 of 2020. Media responses will be identified from reporting data that the media routinely publish. In this case, the authors chose the national media: Kompas, Tempo, and Detik as national media that were perceived independently.

This research was conducted for 30 days in part 1 to 30 April 2020. The unit of analysis is some news and opinions related to pandemics from newspeople. Towards a number of news about Covid-19 identified, authors analyzed to find some patterns of media response trends. The analysis uses a taxonomic way by marking every trend towards the news and putting it in a certain response pattern category. The pattern of media response, 
taxonomically, manifests into 3 patterns: positive, which means support; neutral, and resistance, which means rejecting.

\section{Results and Discussion}

\subsection{A quick look at Tempo, Detik and Kompas Newspapers}

Tempo, Detik, and Kompas newspapers are the most popular news media and are very much in demand by the public. The allure that makes the public like these three media is the character of independence, impartiality, professionalism, and the strength of the data accuracy in presenting the news. This fact can be seen from the survey results of Soegeng Sarjadi School of Government (SSSG) with a survey for the most popular media category in 2013. The survey was conducted by telephone interview method. Numbers are randomly selected from Telkom's telephone directory. Survey population of all Indonesian citizens living in 10 major cities: DKI Jakarta, Surabaya, Bandung, Semarang, Medan, Makassar, Yogyakarta, Palembang, Denpasar and Balikpapan. Respondents were interviewed as many as 2450 people with research time on 3-22 June 2013. 99 percent confidence level with sampling error $-/+2.61 \%$.

This research found, first, for the online media category, Detik.com was the first highest ranking media with $20.8 \%$. Followed in second place was Kompas.com $17.7 \%$, and third place was Tempo.co 5.1\%. Second, Tempo Magazine won the most popular magazine category with 39.5\%, followed by Femina Magazine 15.3\% and Genie Magazine 14.6\%. Third, in the print media category, Kompas Daily and Tempo Magazine were the most popular media in 2013 Detik [10].

\subsection{Media Response to Covid-19 Economic Policy}

Research with content and cultural analysis is intended to recognize patterns of media response to the implementation of national economic policies to overcome the impact of Covid-19. For 30 days ( 1 to 30 April 2020), author observed all the news about Covid-19 in the three national media and found the distribution of the number of news as listed in the following table1.

Table 1. Number of News on Pandemic Covid-19 Issues

\begin{tabular}{|l|c|c|}
\hline Media Name & f & \% \\
\hline $\begin{array}{l}\text { Kompas } \\
\text { newspaper }\end{array}$ & 27 & 31,76 \\
\hline Tempo Magazine & 21 & 24,70 \\
\hline Detik.Com & 37 & 43,52 \\
\hline Amount & 85 & 100,00 \\
\hline
\end{tabular}

Source: Primary Data Analysis, 1 - 30 April 2020

Based on table 1, it is seen that the amount of news about Covid-19 issues during the period 1 to 30 April 2020 is quite evenly distributed. Even though, Detik.com showed a more prominent number of observations, namely 37 news $(43.52 \%)$; followed by Kompas newspaper 27 news (31.7\%), and Tempo Magazine 21 news (24.70\%). Apparently, all three media paid serious attention to the impact of the corona outbreak. The themes of the reporting are varied, following developments that are ranging from substantive themes to light themes to entertain readers. A number of widely reported themes include: national economic policy 14 news (16.7\%), health lifestyle 16 news (18.8\%), conflict and violence 7 
news $(08.2 \%)$, national health policy 12 news $(14,1 \%)$, health protocol 11 news $(12.9 \%)$, cultural response and community participation 17 news (20.0\%), and Eid al-Fitr 8 news (9.4\%). The complete data can be seen in table 2 below.

Table 2. News Theme of Pandemic Covid-19 Issues

\begin{tabular}{|l|c|c|c|c|}
\hline Media Name & Kompas & Tempo & Detik & $\begin{array}{l}\text { Amount } \\
(\%)\end{array}$ \\
\hline $\begin{array}{l}\text { National } \\
\text { economic } \\
\text { policy }\end{array}$ & 4 & 4 & 6 & $\begin{array}{c}14 \\
(16,7 \%)\end{array}$ \\
\hline $\begin{array}{l}\text { Health } \\
\text { lifestyle }\end{array}$ & 5 & 4 & 7 & $\begin{array}{c}16 \\
(18,8 \%)\end{array}$ \\
\hline $\begin{array}{l}\text { Conflict and } \\
\text { Violence }\end{array}$ & 2 & 1 & 4 & $7(8,2 \%)$ \\
\hline $\begin{array}{l}\text { Health policy } \\
\text { Health } \\
\text { protocol }\end{array}$ & 4 & 3 & 5 & $\begin{array}{c}12 \\
(14,1 \%)\end{array}$ \\
\hline $\begin{array}{l}\text { Cultural } \\
\text { Response and } \\
\text { Community } \\
\text { Participation }\end{array}$ & 6 & 4 & 7 & $\begin{array}{c}11 \\
(12,9 \%)\end{array}$ \\
\hline $\begin{array}{l}\text { Eid al-Fitr } \\
\text { event }\end{array}$ & 3 & 2 & 3 & $\begin{array}{c}17 \\
(20,0 \%)\end{array}$ \\
\hline \begin{tabular}{l} 
Amount \\
\hline
\end{tabular} & 27 & 21 & 37 & $\begin{array}{c}85 \\
(100 \%)\end{array}$ \\
\hline
\end{tabular}

Source: Primary Data Analysis, 1 to 30 April 2020

Furthermore, related to the sense of news how the media respond to economic policy can be observed through the statements of the sources in the some news. First, news about economic growth (Kompas, Detik.Com, 2 April 2020). Written in the news, based on the results of an assessment conducted by the Ministry of Finance, the Bank of Indonesia, and the FSA, with the worst scenario Indonesia is likely to experience an economic slowdown of minus $0.4 \%$. If not handled seriously, it can disrupt an investor confidence, the tourism sector, supply chain and financial markets. The prospect of a weakening economy is further compounded by the tendency of weakening global crude oil prices.

Minister of Finance Sri Mulyani together with the Financial Sector Stability Committee (KSSK) has conducted an assessment and predicted the toughest scenarios to be faced are as shown in table 3 below. 
Table 3. The Most Difficult Scenario of the Covid-19 Impact in the Economic Sector

\begin{tabular}{|l|c|c|c|}
\hline \multirow{2}{*}{ Indicator } & \multirow{2}{*}{$\begin{array}{c}\text { APBN } \\
\text { (State } \\
\text { Budget) }\end{array}$} & Difficult & $\begin{array}{c}\text { Very } \\
\text { Difficult }\end{array}$ \\
\cline { 3 - 4 } & 5,3 & 2,3 & $-0,4$ \\
\hline $\begin{array}{l}\text { GDP growth } \\
(\%)\end{array}$ & 14,4 & 17,5 & 20 \\
\hline $\begin{array}{l}\text { Rupiah } \\
\begin{array}{l}\text { Exchange Rate } \\
\text { (Rp / USD) }\end{array}\end{array}$ & 3,1 & 3,9 & 5,1 \\
\hline Inflation & & & \\
\hline
\end{tabular}

Source: Statement of the Minister of Finance (Kompas, Detik, on April 2, 2020)

Based on Sri Mulyani's statement, in a severe scenario, the Indonesian economy is estimated to only grow $2.3 \%$ or down 3\% compared to the assumption of the 2020 State Budget. And a very severe scenario is that the Indonesian economy could decline to minus $0.4 \%$. In comparison to the 2008 financial crisis, the actual conditions that occurred in 2009 , the Indonesian economy was still able to grow at $4.6 \%$, where in 2008 it was $6 \%$, or down $1.4 \%$. This means that from this scenario, it can be said, the economic downturn for a severe scenario will be 2 times worse than the actual one that occurred in 2009 and for a very severe scenario the impact is 4 times worse than the 2008-2009 economic crisis.

Secondly, the news about the 2020 economic crisis is far worse than the economic crisis in 2008-2009. Why is the 2020 crisis said to be worse than 2008? Sri Mulyani said, 'it was all because Indonesia was still able to withstand its impact on the economic structure, which was largely supported by the domestic consumption sector. And at that time, the community was still able to carry out their normal activities, Likewise with MSMEs that were not related to export and import, they all could still operate normally.

The current situation is much different, the corona pandemic at the level of damage to the consumption level of the people below. Meanwhile, to control the spread of this virus, one government has asked people to stay at home and replace outside activities. Schools are closed, office workers order work at home, tourist attractions and entertainment are closed. With the stopping activity, the small shops around the location will be stopped.

Third, news about anticipation to face the worst scenario in Tempo Magazine, Kompas, Detik.Com, April 4, 2020. Sri Mulyani said, although the assessment results showed such a frightening condition, she stressed, it was this assumption that would be the benchmark so as not to get to the worst scenario happen. That is why the government is trying to issue policies and stimulus to reduce the impact of Covid-19

Facing such a situation, on April 1, 2020, President Joko Widodo signed Government Regulation in Lieu of Law (PERPU) No. 1 of 2020 concerning State Financial Policy and Financial System Stability, which is determined by the government to increase spending and budget financing to handle the impact of Covid-19 by Rp 405.1 trillion. Details of the use of such funds can be seen in table 4 below. 
Table 4. Expenditures and Budgets for Dealing with the Impact of Covid-19

\begin{tabular}{|l|l|l|}
\hline Priority & Description & $\begin{array}{l}\text { Value } \\
\text { (trillion) }\end{array}$ \\
\hline Health & $\begin{array}{l}\text { Medical personnel } \\
\text { incentives and } \\
\text { health care } \\
\text { spending }\end{array}$ & 75 \\
\hline $\begin{array}{l}\text { Social } \\
\text { protection }\end{array}$ & Social Safety Net & 110 \\
\hline $\begin{array}{l}\text { Industry } \\
\text { support }\end{array}$ & $\begin{array}{l}\text { Taxes, import } \\
\text { duties, people's } \\
\text { business credit } \\
\text { (KUR) }\end{array}$ & 70,1 \\
\hline $\begin{array}{l}\text { Economic } \\
\text { recovery }\end{array}$ & $\begin{array}{l}\text { National economic } \\
\text { recovery program }\end{array}$ & 150 \\
\hline $\begin{array}{l}\text { Total Additional Expenditures and } \\
\text { Budget Financing }\end{array}$ & 405.1 \\
\hline
\end{tabular}

Source: Detik.Com on April 5, 2020

Based on table 4, details of the use of the budget, among others, are aimed at: First priority for health financing of Rp. 75 trillion, especially for medical personnel incentives and health care spending. The second priority for the expanded social safety net is $\mathrm{Rp} 110$ trillion. The third priority is support to the industry worth $\mathrm{Rp} 70.1$ trillion (taxes, import duties, KUR). Finally the 4th priority is funding support for the economic recovery program budget of Rp 150 trillion.

Regarding the budget allocation for economic recovery policies, the media gave some responses. Starting from Kompas Newspaper, for example, from 4 news data, it shows that the compass provides a positive perception of this policy. Naturally, the state is present to overcome severe problems if the state is neglected. The same perception was also shown by Tempo Magazine (3 news), and Detik.Com (4 news) which led to support. From overall news, there are only 2 news that show negative tune. This negative attitude is related to the shortcomings of PERPU No. 21 of 2020 which allows opportunities for the abuse of power. It is in the media's interest to criticize that point. Table 5 below shows the media response to the implementation of covid-19 economic policy.

Table 5. Tune in News Presentation on Covid-19 Economic Policy Issues

\begin{tabular}{|l|c|c|c|c|}
\hline \multirow{2}{*}{ Media Name } & \multicolumn{3}{|c|}{$\begin{array}{c}\text { Tune in News } \\
\text { Presentation on } \\
\text { Covid019 Economic } \\
\text { Policy }\end{array}$} & $\begin{array}{c}\text { Amou } \\
\text { nt }\end{array}$ \\
\cline { 2 - 4 } & $\begin{array}{c}\text { Positiv } \\
\text { e }\end{array}$ & $\begin{array}{c}\text { Neutr } \\
\text { al }\end{array}$ & $\begin{array}{c}\text { Negati } \\
\text { ve }\end{array}$ & \\
\hline $\begin{array}{l}\text { Kompas } \\
\text { Newspaper }\end{array}$ & 3 & 1 & 0 & 4 \\
\hline $\begin{array}{l}\text { Tempo } \\
\text { Magazine }\end{array}$ & 3 & 0 & 1 & 4 \\
\hline Detik.com & 4 & 1 & 1 & 6 \\
\hline Amount & 10 & 2 & 2 & 14 \\
\hline
\end{tabular}




\subsection{Populism: Common Belief of State and Media}

The state, setting policies is not free of interest. Likewise the media, with respect to the language displayed in the news is not a neutral language, without values or without interest. The state, of course, has an ideology in economic growth so as not to minus, unemployment decreases. So for state, providing social protection for vulnerable groups is a top priority in handling covid-19. The media also hopes the state to protect the vulnerable groups. At this point, populism is a common perspective shared by the media and the state in responding to national economic policies $[11,12,13]$.

In this regard, the government in mitigating the impact of the Covid-19 pandemic needs to consider the situation of social unrest experienced by affected groups. Researchers suggest two strategies to the government, namely the strategy of providing access to the fulfillment of basic needs (basic needs access) by providing direct assistance programs to fulfill basic needs; and sustainability livelihood access strategies aimed at providing opportunities for vulnerable groups to have sustainable livelihoods. These two strategies are important so that vulnerable groups are not increasingly marginalized $[14,15,16]$.

\section{Conclusion}

The media's response to national economic policy to overcome the covid-19 pandemic, is very diverse. But the most prominent response is shown by the way of thinking that gives a positive view of state policy. And, positive perceptions from the media arise because of a common perspective, namely populism, which becomes a meeting point for the interests of the media and the state to meet. Populism is a way of looking at the protection of vulnerable groups as a primary. This meeting point needs to be maintained, and that only happens when mitigating the impact of a pandemic covid-19 while considering economic vulnerability experienced by vulnerable groups. To them, social protection programs need to be provided that lead to the fulfillment of basic needs and opportunities for sustainable livelihoods.

So in that context, researcher suggest that the government must be implement two strategies namely the strategy of basic needs access by providing some direct assistance programs to fulfill the needs of their daily life; and sustainability livelihood access strategies aimed at providing opportunities for sustainable livelihoods. These two strategies are important so that vulnerable groups are not increasingly marginalized.

Anthropologically, this research needs to be followed up by examining how the government formulates policy handling for vulnerable groups through a study on anthropology of policy. From this review, it can be recognized how the contestation in the preparation of "public policy" takes place dynamically.*

\section{Acknowlegments}

This research is supported by faculty intended to write this article. Even so this article could be completed because of the support of many parties. For that, I am on this good opportunity, I thank Prof. Dr. Yos Johan Utama as Rector and Dr. Nurhayati as Dean of the Faculty of Humanities, Diponegoro University, who had provided administrative support until this article was realized. In addition to the chief editor of Kompas Newspaper, Tempo Magazine, and Detik.Com who have given permission, the media is the object of research 
studies for the sake of the compilation of this scientific publication. Without their support this scientific work would not have been possible.

\section{References}

1. Joharudin, Agus. Panic Syndrome COVID-19 : Penekanan terhadap Kebijakan yang Diberikan Pemerintah. Jurnal Persoektif. 4, 1. p 44-53 (2020)

2. Selasi, Dini. Dampak Pandemic Disease terhadap Perkembangan Pasar Modal Syariah Indonesia. Syntax Literate: Jurnal Ilmiah Indonesia. 5, 1 (2020)

3. A Spinelli, G-Pellino. COVID-19 Pandemic: Perspectives on an Unfolding Crisis. British Journal Surgery. (2020)

4. Fransesco Pinotti, et al. Lesson Learnt from 288 Covid-19 International Cases: Importations Over Time, Effect of Interventions, Underdetection of Imported Cases. MedRxiv Journal. 1 (2020)

5. Laidlaw, Tess. Pandemic Stories: Rhetorical Motifs in Journalists : Coverage of Biomedical Risk. Minerva. 57. p 433-451 (2019)

6. Triyaningsih, Heni. Efek Pemberitaan Media Massa terhadap Persepsi Masyarakat tentang Virus Corona (Studi Kasus : Masyarakat di Pamekasan). MEYARSA : Jurnal IImu Komunikasi dan Dakwah. 1, 1 (2020)

7. Mediantara, Yogi; Dani, Jeratallah Aram. Covid-19 dan Perubahan Komunikasi Sosial. PERSEPSI: Communication Journal. 3, 1. p 94-102 (2020)

8. Setiawan, Rifki, Adib. Lembar Kegiatan Literasi Saintifik untuk Pembelajaran Jarak Jauh Topik Penyakit Coronavirus 2019 (COVID-19). Jurnal Edukatif : Jurnal Ilmu Pendidikan 2, 1. p 28-37 (2020)

9. Manson, Katherine A. 2015. "H1N1 Is Not A Chinese Virus: The Racialization of People and Viruses in Post-SARS China". St Comp Int Dev. 50. p 500-518 (2019)

10. Detiknews. Detik.com, Harian Kompas dan Majalah Tempo Terpopuler 2013. July, 20 (2013). Link:https://news.detik.com/berita/2313535/detikcom-harian-kompas-danmajalah-tempo-media-terpopuler-2013-

11. Levi-Strauss. Structural Anthropology. vol. 2. New York: Basic Book. (1976)

12. Rashid N Lui, et al. Overview of Guidence for Endoscopy During the Corovirus Disease 2019 (COVID-19) Pandemic. Journal of Gastroenterology and Hepatology. 35. 749-759 (2020)

13. Mas'udi, Wawan ; Poppy S Winarti (ed). Tata Kelola Penanganan COVID-19 di Indonesia : Kajian Awal. Yogyakarta : GajahMada Pers. ISBN : 978-602-386878-0. Cetakan 1. (2020).

14. Fara Dwi Sakti Kartika, et al. Meta-analysis of community's adaptation pattern with tidal flood in Pekalongan City, Central Java, Indonesia. E3S Web of Conferences. 125, 09001 (2019)

15. Muhammad Israr, Humayun Khan, Dawood Jan, Nafees Ahmad. Livelihood Diversification: A Streatagy for Rural Income Enhancement. Journal of Finance and Economics 2, (5). pp 194-198. (2014)

16. MH Hidayattuloh, et al. Environmental-based budget planning in The Tegal Regency Government. E3S Web of Conferences, 125, 09001 (2019). 